\section{Soil Mounding as a Control for Dogwood Borer in Apple}

\author{
Larry J. Gut, ${ }^{1,2}$ Peter H. McGhee, ${ }^{2}$ and Ron Perry ${ }^{3}$ \\ Michigan State University, East Lansing, MI 48824
}

Additional index words. burrknot, rootstock, Sesiidae, Synanthedon scitula, cultural control, reduced insecticides

Abstract. The relationship between the extent of burrknots on apple rootstocks and dog-
wood borer (DWB) [Synanthedon scitula Harris] infestation, and the efficacy of a cultural
management strategy for this pest were studied in heavily infested plots at the Michigan
State University Clarksville Horticulture Experiment Station. Spearman rank correla-
tion Rho values of 0.85 and 0.75 in consecutive years of the study substantiated a strong
positive correlation between the number of larvae present in the rootstock and the surface
area of the rootstock covered by burrknots. Cultivar type affected the level of the DWB
infestation in the rootstock. Larval densities were 8- to 10-times higher in Mark rootstocks
when the grafted scion was 'Idared' instead of 'Liberty'. This cultivar related difference
in larval infestation was associated with a greater number of burrknots on 'Idared'Mark
compared to 'Liberty'/Mark trees. Mounding of soil to cover the exposed rootstock was
found to be a highly effective alternative to insecticides for DWB control. Under condi-
tions of heavy pest pressure, this cultural control tactic provided $76 \%$ to $99 \%$ reductions
in larval densities. These levels of control are comparable to or better than those reported
for trunk sprays with chlorpyrifos, the most effective of currently available insecticides.

Dogwood borer (DWB) (Synanthedon scitula Harris), is a clearwing moth native to North America. It has a broad host range that includes a variety of woody ornamentals, especially flowering dogwood (Cornus florida L.) (Engelhardt, 1946; Taft et al., 1991). Adults deposit eggs in bark crevices and hatching larvae generally enter the host through small wounds or cracked callous growth. Larval feeding in the phloem and cambium causes girdling of larger branches or the trunk. The DWB is thought to be univoltine, although some studies have documented two distinct periods of activity (Bergh and Leskey, 2003; Eliason and Potter, 2000; Potter and Timmons, 1983).

Apple, cherry and pecan are among the fruit and nut crops that are known hosts of the DWB. Within the past 20 years, this sesiid has become a serious pest of commercial apple in eastern North America (Kain and Straub, 2001; Pfeiffer and Killian, 1999; Riedl et al., 1985; Warner and Hay, 1985). This increased pest status has paralleled the introduction and extensive planting of dwarfing and semidwarfing rootstocks. The presence of DWB larvae is generally associated with the presence of burrknots (Riedl et al., 1985; Warner and Hay, 1985), which are a non-pathological proliferation of adventitious root initials occurring on the above ground portion of some of these clonal rootstocks (Rom, 1970; Rom

Received for publication 14 Apr. 2005. Accepted for publication 18 Aug. 2005. This research was supported by Michigan State University (MSU) Project GREEEN, grant GR99-082. We thank Gail Byler for assistance in data collection. The manuscript was improved by comments from J.C. Bergh and T.C. Leskey.

${ }^{1}$ To whom reprint request should be addressed; emailgut@msu.edu.

${ }^{2}$ Department of Entomology.

${ }^{3}$ Department of Horticulture. and Brown, 1973; Swingle, 1925). Chronic can severely reduce tree vigor and result in tree death (Weires, 1986).

At least one insecticide application using a handgun sprayer directed at the trunk of the tree between first and peak egg hatch has proved to be the most effective tactic for chemical control of DWB in apple (Kain et al., 2002, 2003). Chlorpyrifos is the most efficacious insecticide. However, changes in pesticide regulations, especially the passage of the Food Quality Protection Act (Public Law No. 104170), threaten the availability of this material. All foliar uses of chlorpyrifos after bloom in apple have already been eliminated.

Some reduced-risk controls for this pest in apple have been tested over the past 15 years, but their effectiveness has generally been variable or inadequately demonstrated. In an unreplicated 3-year trial, Pfeiffer and Killian (1999) found that pheromone-based mating disruption did not control a DWB population infesting 'Gala' apples on a dwarfing rootstock. Atrunk application of latex paint apparently can impede entry by larvae, but this tactic has been less effective than insecticide sprays (Riedl et al., 1985; Warner and Hay, 1985). Riedl et al. (1985) indicated that DWB could be controlled in established apple plantings by berming with soil to prevent access to burrknots, but did not provide data supporting the effectiveness of this approach. It has also been suggested that mounding of soil around the exposed portion of rootstocks could control DWB by limiting or preventing burrknot formation in early tree development (Warner and Hay, 1985; Young

The popularity of dwarfing and semi-dwarfing apple rootstocks continues to increase. More than $56 \%$ of acreage in Michigan is planted to these types, with $35 \%$ of all apple varieties planted on M.9, M.26, or MM106 DWB infestations in apple over several years and Tyler, 1983).
(Kleweno and Matthews, 2001). Unfortunately, an increased incidence of burrknots and DWB infestations in Michigan apples has accompanied the industry's move to these size-controlling rootstocks (R. Perry, unpublished data).

Dwarfing apple rootstocks differ in their propensity to produce burrknots (Marini et al., 2003; Rom, 1970; Rom and Brown, 1973). Furthermore, the extent of burrknot formation is affected by site and environmental conditions. Burrknot severity was influenced by rootstock at 9 of the 20 plantings in a regional rootstock trial (Marini et al., 2000). After five growing seasons at the Michigan site trees on Mark and M.26 rootstocks had a higher number of burrknots than other rootstocks. Across all regions the severity of burrknot development was linearly related to rootstock exposure above ground. However, this relationship varied by site (Marini et al., 2000).

In response to having few options available for DWB control, as well as concerns over the cost and safety of handgun application of insecticides, we initiated efforts to develop an alternative management approach for control of this increasingly problematic pest species. The aim of the study reported herein was to examine burrknot and cultivar effects on DWB infestation, and to determine the effectiveness of a cultural control tactic for this pest consisting of mounding of soil to cover the exposed rootstock.

\section{Materials and Methods}

Plots. Studies were conducted from 1998-2000, following the discovery of severe infestations of DWB in young apple plantings at the Michigan State University Clarksville Horticulture Experiment Station. The experimental plots consisted of eight 0.21-ha apple orchards that were established in 1994 to conduct research on novel pest controls in apple. In each plot 104 trees each of the following three cultivar/rootstock combinations were planted at a $1.5 \times 4.5 \mathrm{~m}$ spacing: 'Idared'/Mark; 'Empire'/M 9 EMLA; and 'Liberty'/Mark. There were four rows per cultivar, 26 trees in length, running in a north-south direction, and trained to a slender spindle system with a target height of $3.0 \mathrm{~m}$. Each tree was supported by a $2.5-\mathrm{m}$ high metal tube and high tensile wire stretched across the row at a 2.2-m height.

The eight small orchards were established as four pairs of plots with at least $100 \mathrm{~m}$ between them (Fig. 1). A hedgerow barrier was established along the perimeter of one orchard of each pair. The hedgerow consisted of three rows of hybrid poplar (Populus deltoides Bartr. $\times$ P. nigra L.), one row of Italian alder (Alnus cordata L.), and one row of white pine (Pinus strobus L.). Apple trees and hedgerows were irrigated with a trickle irrigation system. Trees were irrigated during each growing season with scheduling based on satisfying $100 \%$ of a Class A evaporative pan.

Various pest management programs were employed in each 0.2-ha plot for control of insect pests other than DWB over the 3-year course of the study (Garcia-Salazar et al., 2005). 
However, none of the management programs included insecticide sprays directly impacting DWB. All plots were treated the same in terms of weed and mammal control over the course of the study. Glyphosate was used during the growing season to control weeds in tree rows, and regular mowing suppressed the grass/groundcover between rows. Tree trunks were protected to a height of $30 \mathrm{~cm}$ from voles and rabbits using 20 -cm-diameter plastic open mesh cages.

Monitoring seasonal activity. Pheromonebaited traps were used to monitor the flight of DWB males in each year of the study. A single large plastic delta (LPD) trap baited with a rubber septa lure containing 1 milligram of Z,Z-3,13-octadecadien-1-ol acetate (Scenturion, Inc., Clinton, Wash.) was placed in each plot. The lure manufactured by Scenturion is the most attractive of those commercially available for monitoring DWB (Bergh et al., 2004). The trap was placed in the center of each plot at a height of 1.2 to $1.6 \mathrm{~m}$. Traps were inspected weekly from mid-May until mid-September. Captured DWB males were counted and removed at each inspection. Other insects and debris were also removed at this time to maintain the availability of the sticky surface for insect capture. Lures were replaced every 6 weeks and sticky inserts were changed once per generation.

Scion cultivar susceptibility. The effect of scion cultivar on susceptibility of Mark rootstock to DWB was determined by comparing larval infestation in two cultivars, 'Liberty' and 'Idared'. 'Burrknots were counted on the rootstock shank of each tree. In 1998, the trunk areas of all 104 trees in each plot were inspected between 8 and 22 May,before the emergence ofDWB adults. After removing the tree guards, tree trunks and surrounding soil were examined for pupal exuvia and evidence of frass and other signs of DWB activity. Trunk areas with evidence of larval attack, as well as all wounded areas and burrknots, were inspected to determine if any live DWB larvae were present. Data collected in this initial year of the study consisted of classifying sample trees into those with trunks infested by DWB (larva detected) or not infested by DWB (no larva found). The frequency of infestation of 'Liberty' and 'Idared' was compared using Chi Square analysis (SAS Institute, 2000).

In 1999 and 2000, the trunks of 16 'Liberty' and 'Idared' trees were randomly chosen in each of the eight plots, and inspected for evidence of DWB as previously described. However, unlike in the 1998 sample, a thorough inspection of wounded areas and burrknots was conducted to determine the total number of DWB larvae infesting each tree. The process entailed carefully digging into wound and burrknot tissue using a paring knife and extracting all larvae found. Different sets of trees were examined in 1999 and 2000. The mean number of larvae infesting the rootstocks of 'Liberty' and 'Idared' trees was compared using a MannWhitney $\mathrm{U}$ test for nonparametric data (SAS Institute, 2000).

Relationship between burrknots and DWB abundance. In 1999 and 2000, burrknot measurements were also taken to investigate the relationship between severity of burrknot formation and abundance of DWB. The proportion of the trunk area covered with burrknots was estimated in both years before larval sampling and ranked in increments of 10 from $0 \%$ to $100 \%$. The relationship between area of rootstock covered with burrknots and larval infestation levels was tested for significance using Spearman's rank correlation (SAS Institute, 2000).

Soil mounding to control DWB. 'This experiment was initiated in October 1998 after all DWB flight activity for the season had ended. The two experimental treatments were rootstocks mounded and rootstocks not mounded. The mounding treatment entailed covering the rootstock of each tree with a sandy soil to a height of at least $5 \mathrm{~cm}$ above the graft union. The soil used for mounding was the $\mathrm{C}$ horizon of a Kalamazoo sandy loam that is described as either sandy, coarse sand, gravelly sand, or stratified sand (Soil Survey Staff, 2005). In an effort to limit the loss of trees in these plots to extensive DWB injury, we opted to mound

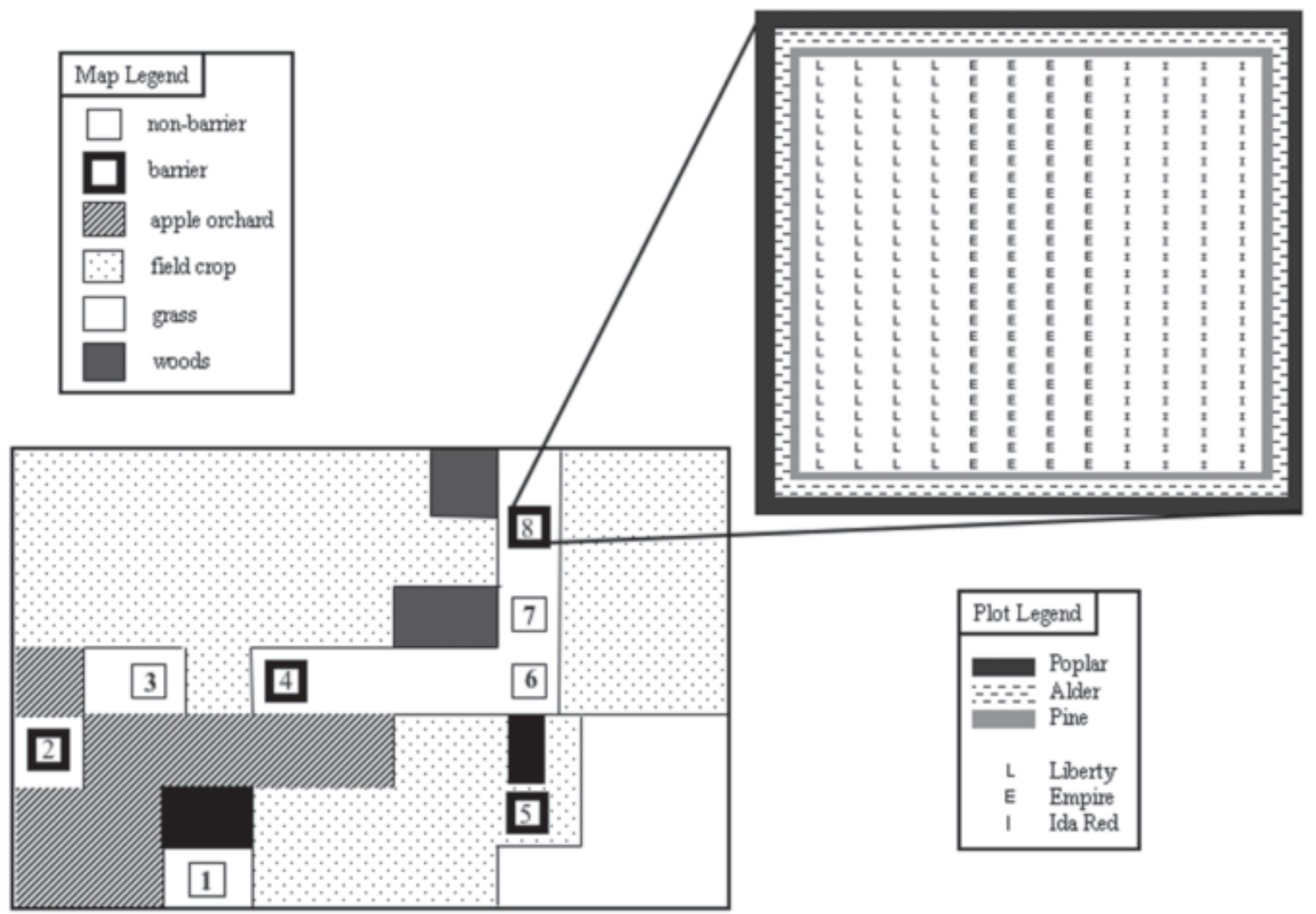

Fig. 1. Locations of the eight 0.2-ha experimental apple plots relative to each other and to other plantings at Michigan State University Clarksville Horticulture Research and Extension Center. 


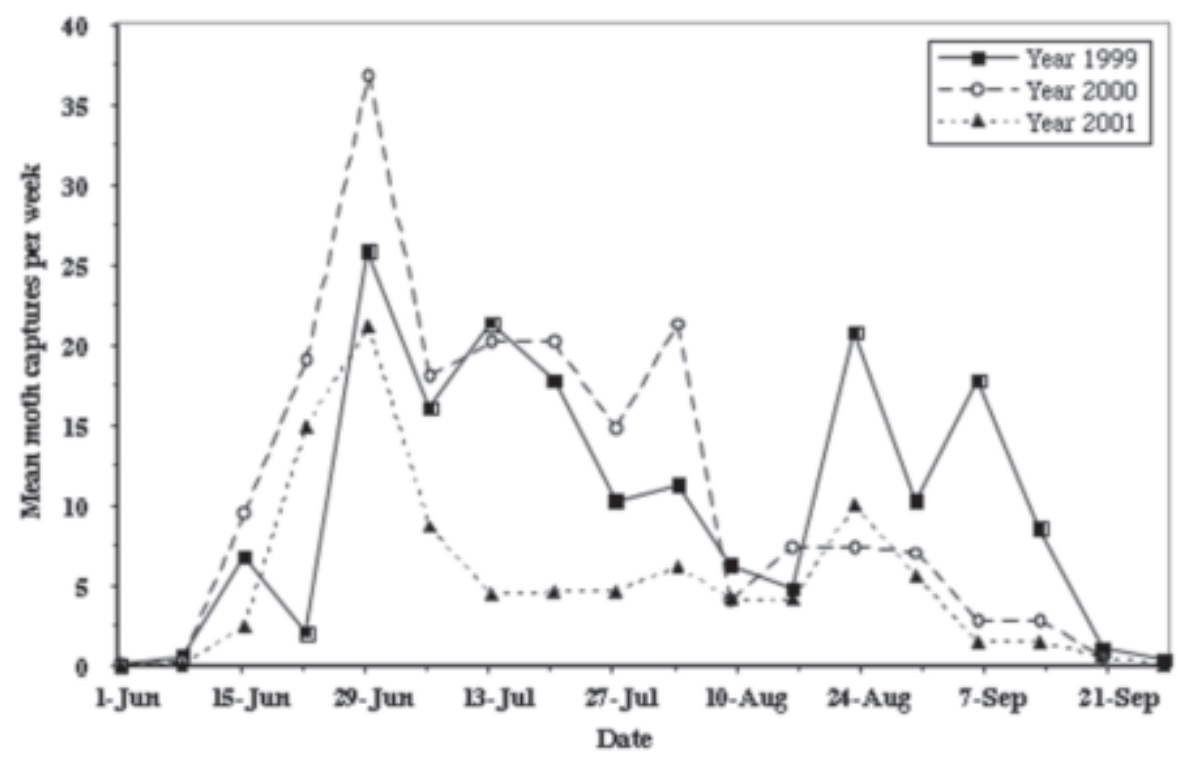

Fig. 2. Captures of Synanthedon scitula males in pheromone traps, 1999-2001.

Table 1. Susceptibility of two apple cultivars on Mark rootstock to Synanthedon scitula infestation.

\begin{tabular}{|c|c|c|c|c|}
\hline \multirow[b]{2}{*}{ Cultivar } & \multicolumn{2}{|c|}{ Frequency of infestation in 1998} & \multicolumn{2}{|c|}{ Mean larvae per tree } \\
\hline & Not infested & Infested & 1999 & 2000 \\
\hline Liberty & 754 & 71 & 0.97 & 1.24 \\
\hline Idared & 479 & 353 & 7.61 & 12.11 \\
\hline & \multicolumn{2}{|c|}{$p<0.0001^{z}$} & $p<0.0001^{\mathrm{y}}$ & $p<0.0001$ \\
\hline
\end{tabular}

${ }^{\mathrm{z} C h i-s q u a r e}$ analysis.

yMann Whitney U test.

the majority of trees. A total of 248 trees per plot were mounded. 'They included all of the 'Empire'/M.9 and 72 of the 104 'Liberty'/Mark and 'Idared'/Mark, respectively. In each plot, 32 randomly selected 'Liberty' and 32 'Idared' trees were not mounded with soil and served as the untreated checks. All 'Empire'/M.9 trees were mounded with soil to avoid insect damage and because this scion/rootstock combination would provide an unbalanced treatment in the study.

The effect of mounding on DWB was determined by comparing larval densities in mounded versus those in exposed rootstocks. Larval counts were made in early May of 1999 and 2000, before the emergence of any adults, by examining wounds and burrknots and extracting larvae as previously described. In 1999, soil was removed from around the shanks of 16 'Liberty' and 16 'Idared' trees per plot. The sample trees were randomly selected from among the 72 trees of each cultivar per plot that had been mounded in October of the previous year. Larval counts were taken on the rootstocks of these 32 trees and the rootstocks of 16 'Liberty' and 16 'Idared' trees that had been left exposed the previous season. In 2000, soil was removed from around the shanks of another 16 'Liberty' and 16 'Idared' trees per plot, randomly selected from among the remaining 56 trees of each cultivar that had been mounded in October 1998. The rootstocks of these 32 trees and the rootstocks of the remaining 16 'Liberty' and 16 'Idared' trees with exposed rootstocks (not mounded in 1998) were examined for DWB infestation as previously described. The mean larval counts on exposed and mounded rootstocks, and on exposed rootstocks of 'Liberty' and 'Idared' were compared using a Mann Whitney U test for nonparametric data (SAS Institute, 2000).

\section{Results}

Seasonal activity. The pattern of seasonal activity of DWB as indicated by moth captures in pheromone-baited traps was similar during the 3 years of the study (Fig. 2). The initial capture of males consistently occurred in early June, with peak catches recorded in late June. The highest weekly catch recorded was 37.5 moths per trap in 2000. Average weekly moth captures during the period of greatest DWB activity, late June through July, were substantially higher in 1999 and 2000 than in 2001. Males continued to be captured at levels averaging at least 5 moths per trap into early September in all 3 years. Late season captures were consistently higher in the first year of the study compared to subsequent years.

Scion cultivar effect. The 1998 data show that 'Idared'/Mark trees were more frequently infested with DWB than 'Liberty'/Mark trees (Table 1). At least one DWB larva was detected in $>41 \%$ of the Idared trees while $<9 \%$ of the 'Liberty' trees were infested. In terms of larval density, DWB was eight to ten times higher on Mark rootstocks with the 'Idared' scion than with the 'Liberty' scion in 1999 and 2000, respectively (Table 1).

Relationship between burrknots and DWB abundance. There was a highly significant ( $p$ $<0.0001$ ) association between the extent of burrknots on the rootstock andDWBinfestation in both 1999 and 2000 (Fig. 3). Rho values of 0.85 and 0.75 suggest a strong positive correlation between the number of larvae present in the rootstock and the proportion of the rootstock surface covered by burrknots.

Soil mounding to control DWB. High mean densities of 7.1 and 13.1 DWB larvae per rootstock were detected in exposed rootstocks in 1999 and 2000, respectively. Soil mounding of the rootstock shank significantly reduced DWB infestation in these heavily infested plots in both years (Table 2). The mean number of larvae in mounded compared to exposed rootstocks was reduced by $76 \%$ in 1999 and $99 \%$ in 2000 (Table 2).

\section{Discussion}

Concern that DWB might pose a serious problem for apple growers in Michigan and elsewhere in the midwestern U.S. was greatly elevated in 1997 following the detection of a severe infestation in a suite of young apple blocks at Michigan State University's main horticultural research farm. Subsequently, a survey of DWB infestation in Michigan commercial orchards revealed that many young blocks were infested and that high larval densities were not uncommon (R. Perry, unpublished data). The problem was generally associated with M.26, M.9, and in some cases Mark rootstocks. Surveys to determine the extent of DWB infestations in northeastern apple orchards conducted nearly 20 years ago first documented that many of the clonal apple rootstocks, such as M.9, M.26, and MM106, were especially vulnerable targets for this wood-boring pest (Riedl et al., 1985; Warner and Hay, 1985). These studies also established that infestations were related to the tendency of the size controlling rootstocks to produce resting root primordia or burrknots on the shanks of the exposed rootstock.

Our data concur with this previously reported strong association between burrknots and the incidence of DWB infestation. In addition, the actual density of larvae per tree varied in accordance with the extensiveness of burrknot formation. For at least one susceptible rootstock, Mark, the greater the area of shank covered with burrknots, the heavier the DWB infestation.

Cultivar/rootstock combination also affected the frequency and the level of infestation by DWB. Larval densities in Mark rootstocks were 8 to 10 times higher when the scion cultivar was 'Idared' compared to 'Liberty'. This cultivar related difference in larval infestation was associated with a greater number of burrknots on 'Idared'/Mark compared to 'Liberty'/Mark trees. Previous research also indicates a potential for differences in susceptibility to DWB depending on the scion. Rom and Motichek (1987) found that cultivar type had a significant influence on burrknot development on clonal rootstocks, with heavier burrknot formation on nonspur than spur-type cultivars. Riedl et al. (1985) observed large differences in the frequency of DWB on the same rootstock, but with different scions. For example, $78 \%$ of 'Idared'/MM106 trees were 

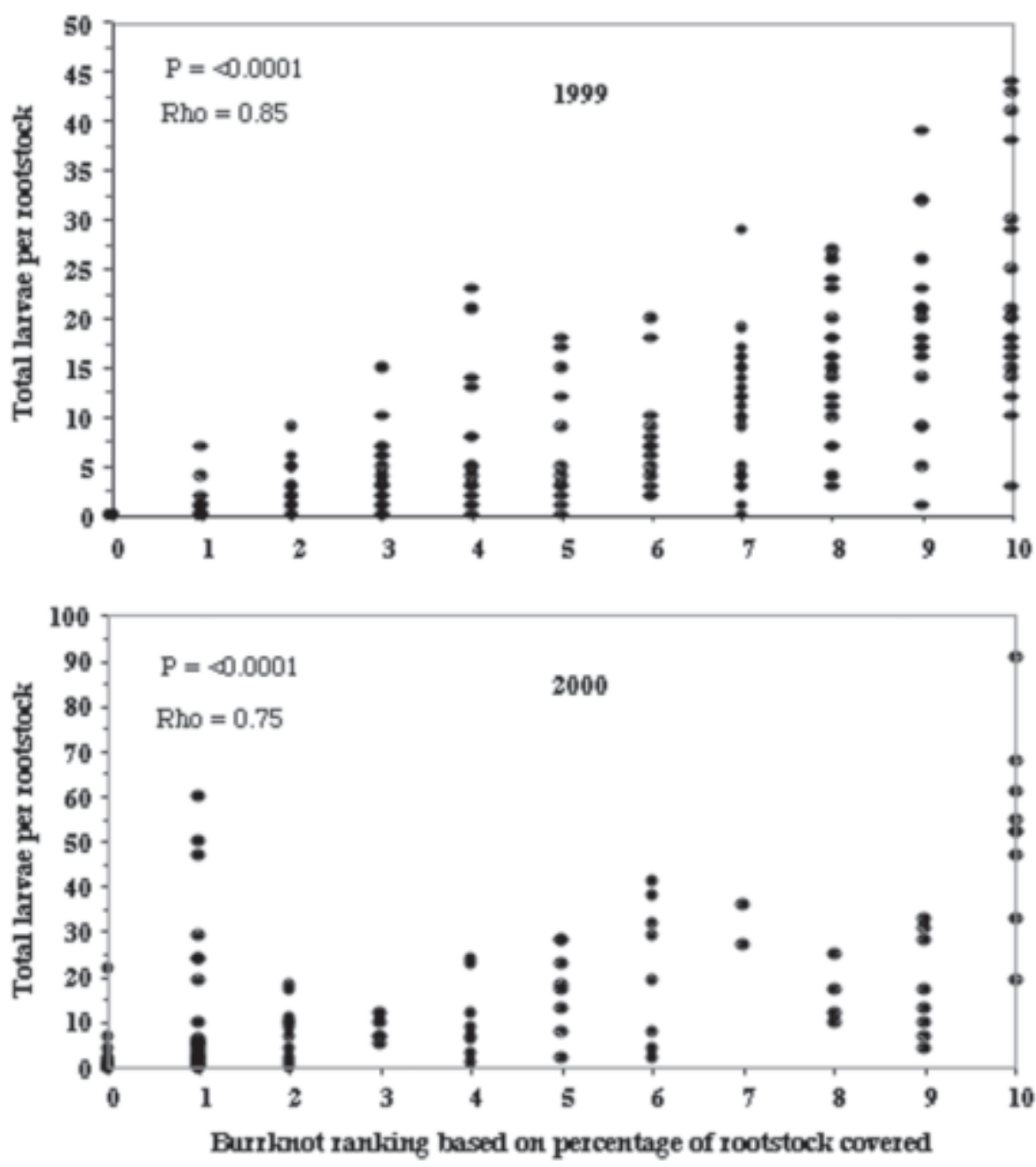

Fig. 3. Relationship between Synanthedon scitula larval densities and the extent of burrknots on Mark apple rootstocks. Burrknot rankings of 1 to 10 were assigned based on estimating the proportion of the trunk area covered with burrknots in increments of 10 from $0 \%$ to $100 \%$.

Table 2. Effect of soil mounding of rootstock on Synanthedon scitula larval densities in apple.

\begin{tabular}{lcc}
\hline & \multicolumn{2}{c}{ Mean larvae/tree } \\
\cline { 2 - 3 } Treatment & 1999 & 2000 \\
\hline Exposed rootstock & 7.13 & 13.10 \\
Mounded rootstock & 1.72 & 0.17 \\
& $p<0.0001^{\mathrm{z}}$ & $p<0.0001$ \\
\hline
\end{tabular}

${ }^{\mathrm{z} M a n n}$ Whitney U test.

infested, while the infestation rate on 'Rome'/ MM106 was only 4\%. Although it appeared that the differences were related to the scion's effect on burrknot formation, the researchers were unable to demonstrate this because the measurements for each cultivar/rootstock were from different orchards.

Riedl et al. (1985) proposed the use of soil mounding for DWB control, but did not provide data to indicate the level of control that could be expected. In our study, mounding of rootstocks under conditions of heavy pest pressure provided $76 \%$ to $99 \%$ reductions in larval densities, levels comparable to or better than those reported for trunk sprays with chlorpyrifos (Riedl et al., 1985; Wise and Gut, 2002). A single trunk application of chlorpyrifos to some of the DWB infested trees in our test plots at the Clarksville Experiment Station in 2001 reduced larval densities by $75 \%$ compared to rooting occurs. At that point, nothing can be done to rectify the problem. Unearthing roots and pruning roots causes the development of a basin that collects water and subsequent winter icing (Perry, 2000). Later, soil settles in and the scion roots return, which again leads to increased tree vigor and management difficulties.

Although the practice of mounding or berming of soil can suppress an existing DWB population, it is probably a costly method of treating an established orchard. The practice of mounding and berming are equivalent in effectiveness to suppress DWB. The construction of a berm is more economical and it can be easily constructed in young and newly established orchards. Berming of tree rows can be accomplished at a reasonable cost by simply using a side tool-bar hoe and should be considered a viable practice for DWB control. Our experience to date suggests that the berm should be formed in the first season, preferably soon after planting while the soil is loose and cultivatable. Inspect the berms during the second growing season to make sure burrknots are covered; follow up with a closer inspection in the third growing season to avoid scion rooting. Should the graft unions be buried by soil, scion rooting may occur within the first 3 years following construction of a berm. Our orchard experience indicates that exposure of newly formed adventitious scion roots to air will functionally disable roots without any negative impact on the tree.

In Fall 1998, we formed a berm on newly established trees with the soil level at 7 to 11 $\mathrm{cm}$ above the graft unions. Inspecting trees in the summer of 1999 revealed that soil had naturally settled to graft union height or below and no scion rooting appeared on trees where some soil still covered the graft union.

It is evident that the increasing prevalence of semi-dwarf and dwarf apple rootstocks has fostered an increase in the incidence and severity of DWB infestation. This insect has a high potential to become an even greater pest of Midwestern and Northeastern apple production systems. Not only are more burrknot-forming rootstocks being planted, but there are few options available for controlling DWB. The availability of the most effective control tactic, insecticide trunk sprays, is jeopardized by worker safety concerns. Even if this approach continues to be allowed, it may not be adequate for suppression of heavy infestations. We have demonstrated that soil mounding of apple rootstocks is a highly effective alternative to insecticides for DWB control. The practice can be adopted for orchards managed conventionally as well as organically. It is highly recommended for new plantings if the rootstocks are known to be prone to burrknot formation, but can also provide excellent control even with densities averaging over a dozen larvae per tree in exposed rootstocks in established plantings.

\section{Literature Cited}

Increasing the number of scion roots negates the influence of the dwarfing rootstock (Ferree and Carlson, 1987). Tree vigor is impacted if a third and especially a fourth year of scion
Bergh, J.C. and T.C. Leskey. 2003. Biology, ecology, and management of dogwood borer in eastern apple orchards. Can. Entomol. 135:615-635. 
Bergh, J.C., T.C. Leskey, and A. Zhang. 2004. Discrimination by male dogwood borer, Synanthedon scitula (Lepidoptera: Sesiidae), among traps baited with commercially available pheromone lures. J. Econ. Entomol. 97:344-352.

Eliason, E.A. and D.A. Potter. 2000. Dogwood borer (Lepidoptera: Sesiidae) infestation of horned oak galls. J. Econ. Entomol. 93:757-762.

Engelhardt, G.P. 1946. The North American clearwing moths of the family Aegeriidae. Smithsonian Inst., U.S. Natl. Museum Bul. 190.

Ferree, D. C. and R. F. Carlson. 1987. Apple rootstocks, p. 107-143. In: R.C. Rom and R.F. Carlson (eds.). Rootstocks for fruit crops. John Wile, New York.

Garcia-Salazar, C., L.J. Gut, and M.E. Whalon. 2005. Impact of two apple production systems on oriental fruit moth, Grapholitha molesta (Busck) (Lepidoptera: Tortricidae) Pest Mgt. J. Alternative Agr. (in press).

Kain, D.P. and R. Straub. 2001. Status of borers infesting apple burr knots and their management in New York orchards. New York Fruit Qurtly. 9:10-12.

Kain, D.P., R. Straub, and A. Agnello. 2002. Apple, evaluation of various trunk sprays to control borers infesting burr knots, 2001. Arthropod Mgt. Tests 27:A42.

Kain, D.P., R. Straub, and A. Agnello. 2003. Apple, evaluation of various trunk sprays to control borers infesting burr knots, 2002. Arthropod Mgt. Tests 28:A10.
Kleweno, D.D. and V. Matthews. 2001. Michigan agricultural statistics 2000-2001. USDA-Natl.Agr. Stat. Serv.-Mich. Dept. Agr. 2000 Annu. Rpt.

Lyons, Jr., C.G., R.E. Byers, and K.S. Yoder. 1983. Influence of planting depth on growth and anchorage of young 'Delicious' apple trees. HortScience 18:923-924.

Marini, R.P., J.L. Anderson, B.H. Barritt, G.R. Brown, J. Cline, W.P. Cowgill Jr., P.A. Domoto, D.C. Ferree, J. Garner, G.M. Greene, C. Hampson, P. Hirst, M.M. Kushad, E. Mielke, C.A. Mullins, M. Parker, R.L.Perry, J.P. Prive, T. Robinson, C.R. Rom, T. Roper, J.R. Schupp, E. Stover, and R. Unrath. 2000. Performance of 'Gala' apple on 18 dwarf rootstocks; A five year summary of the 1994 NC-140 Semi-dwarf rootstock trial. J. Amer. Pomol. Soc 54:92-107.

Perry. R. 2000. Planting fruit trees in 2000. Michigan State University Fruit CAT Alert 15(1):2-4.

Pfeiffer, D.G. and J.C Killian. 1999. Dogwood borer (Lepidoptera: Sesiidae) flight activity and an attempt to control damage in 'Gala' apples using mating disruption. J. Entomol. Sci. 34:210-218.

Potter, D.A. and G.M. Timmons. 1983. Flight phenology of the dogwood borer(Lepidoptera:Sesiidae) and implications for control in Cornus florida L. J. Econ. Entomol. 76:1069-1074.

Riedl, H., R.W. Weires, A. Seaman, and S.A. Hoying. 1985. Seasonal biology and control of the dogwood borer, Synanthedon scitula (Lepidoptera: Sesiidae) on clonal apple rootstocks in New
York. Can. Entomol. 117:1367-1377.

Rom, R.C. and G.R. Motichek. 1987. Cultivar effect on adventitious root development of clonal apple rootstocks. HortScience 22:57-58.

Rom, R.C. 1970. Burrknot observations on clonal apple rootstocks in Arkansas. Fruit Var. Hort. Dig. 24:66-68.

Rom, R.C. and S.A. Brown. 1973. Burrknot characteristics of six clonal apple rootstocks. Fruit Var. J. 27:84-86.

SAS Institute, 2000. SAS/STAT user's guide. version 6. 4th ed. vol. 1. SAS Institute, Cary, N.C.

Soil Survey Staff. 2005. Kalamazoo series soil. http://ortho.ftw.nrcs.usda.gov/osd/dat/K/KALAMAZOO.html.

Swingle, C.F. 1925. Burrknot of apple trees. J. Hered. 16:313-320.

Taft, W.H., D. Smitley, and J.W. Snow. 1991. Aguide to the clearwing borers (Sesiidae) of the North Central States. North-Central Reg. Publ. 394.

Warner, J. and S. Hay. 1985. Observations, monitoring, and control of clearwing borers (Lepidoptera: Sesiidae) on apple in Central Ontario. Can. Entomol. 117:1471-1478.

Weires, R. 1986. Five years research and experience with control of dogwood borer and related burr knot problems. Compact Fruit Tree 19:86-89.

Wise, J. and L. Gut. 2002. Apple: trunk sprays for control of dogwood borer, 2000-2001. Arthropod Mgt. Tests 27:A56.

Young, E. and R.H. Tyler. 1983. Burrknot control on apple. Hort. Sci. 18:921-922. 